DOI: $10.19195 / 2084-5065.48 .7$

\title{
Wielokulturowość w zakładach karnych. Uwagi o problemie i unormowaniach prawnych
}

\author{
PIOTR STĘPNIAK \\ Uniwersytet im. Adama Mickiewicza w Poznaniu
}

\section{Uwagi ogólne}

Kwestia wielokulturowości stała się obecnie jednym z najważniejszych problemów politycznych, społecznych i ekonomicznych, jakie mają do rozwiązania współczesne społeczeństwa. Wpłynęło na to wiele czynników, między innymi swoboda przepływu osób, która jest jedną z podstawowych zasad Unii Europejskiej, systematyczny napływ uchodźców $\mathrm{z}$ regionów objętych konfliktami i wojnami, emigracje ekonomiczne itp. Czynniki te nałożyły się na tradycyjne i historyczne uwarunkowania rozwoju europejskich społeczeństw wielokulturowych, zwłaszcza takie jak tak zwane wędrówki ludów, ekspansje i podboje terytorialne, kształtowanie się i zmiany granic krajów europejskich, na przykład po I i II wojnie światowej oraz rozpad systemu kolonialnego i masowe wyjazdy do metropolii w latach 60 . XX wieku. W takich oto warunkach, w wielu krajach, w populacji sprawców przestępstw coraz bardziej zwiększa się udział osób o zróżnicowanych obywatelstwach, reprezentujących różne narodowości, mówiących różnymi językami, wyznających różne religie i zróżnicowane wartości, należących do różnych mniejszości kulturowych, charakteryzujących się zróżnicowanymi zwyczajami i w inny jeszcze sposób zróżnicowanych kulturowo. $Z$ fenomenem tym wiążą się 
także zjawiska przestępczości zorganizowanej i przestępczości transgranicznej. Konsekwencją jest narastająca wielokulturowość tej grupy przestępców, którzy wymierzoną im karę pozbawienia wolności odbywają w zakładach karnych.

W porównaniu z innym krajami europejskimi, na przykład Francją, Anglią czy też Niemcami, problem ten w warunkach polskich nie jest jeszcze szczególnie poważny. Nie oznacza to jednak, że go nie ma. Można założyć, iż w najbliższych latach jego znaczenie dla systemu penitencjarnego będzie rosło. Polska, jako członek Unii Europejskiej, jest bowiem krajem otwartym, a to oznacza, iż nie może zamykać swoich granic dla cudzoziemców. Oczywiste zaś jest, że pewna ich grupa będzie wchodzić w konflikty z prawem kończące się bezwzględną karą pozbawienia wolności. Mając to na uwadze, warto więc już dzisiaj zapytać, jakie znaczenie dla polityki kryminalnej i penitencjarnej w Polsce ma problem wielokulturowości osób osadzonych w zakładach karnych, jak również w jaki sposób jest on rozwiązywany przez ustawodawstwo penitencjarne. Podniesione kwestie stanowią osnowę i przedmiot rozważań niniejszego artykułu.

We wstępie nieco uwagi należy poświęcić kwestiom terminologicznym, zwłaszcza zaś ogólniejszemu zdefiniowaniu wielokulturowości. Sformułowanie takiej definicji w odniesieniu jej do systemu penitencjarnego pomoże bowiem rozstrzygnąć, o jakie grupy osób pozbawionych wolności tu chodzi.

Określając przesłanki takiej definicji, należy przede wszystkim podkreślić, że postępujące zróżnicowanie kulturowe jest jednym z wyznaczników współczesnej rzeczywistości, a absolutyzm etniczny czy też homogenność społeczeństwa stają się stopniowo, choć nie bez oporów, cechami ustępującymi. W efekcie przeciętny człowiek określa swoją tożsamość kulturową w ciągłym odnoszeniu jej nie tyle do członków różnych wspólnot kulturowych, ile w odniesieniu do kultury dominującej w społeczeństwie, w którym funkcjonuje ${ }^{1}$. Taki stan rzeczy sprzyja jednak patologizacji życia społecznego. Przejawia się ona między innymi $\mathrm{w}$ popełnianiu przestępstw z nienawiści przez przedstawicieli kultury

${ }^{1}$ L. Korporowicz, Wielokulturowość a międzykulturowość, [w:] U progu wielokulturowości. Nowe oblicza społeczeństwa polskiego, red. M. Kempny, A. Kapciak, S. Łodziński, Warszawa 1997, s. 70-71. 
dominującej w warunkach danego państwa, a także w popełnianiu przestępstw przez członków mniejszości etnokulturowych. $Z$ uwagi na to problem wielokulturowości $\mathrm{w}$ procesie oddziaływań penitencjarnych na grupę cudzoziemców nabiera coraz większego znaczenia. Abstrahowanie od kulturowych przesłanek konstruowania własnej tożsamości, poczucia przynależności kulturowej, a także specyfiki reakcji na różnice kulturowe oraz typu relacji na stykach kultur może w tej sytuacji sprowadzić pracę penitencjarną do swoistej nothing work. Innym efektem ignorowania podstawowych wyznaczników tożsamości kulturowej przebywających w polskich zakładach karnych cudzoziemców może być nadanie jej znamion dyskryminacji instytucjonalnej.

Pojęcie wielokulturowości można definiować w dwóch aspektach - opisowym i dynamicznym Jeden i drugi uwzględnia specyfikę wspólnot kulturowych oraz złożoność interakcji zachodzących na stykach kultur ${ }^{2}$. Dla analizy sposobu rozwiązania problemu wielokulturowości przez polski system penitencjarny, a zwłaszcza przez ustawodawstwo penitencjarne, istotne znaczenie ma to, że takie ujęcia eksponują różnice kulturowe oraz ich postrzeganie w perspektywie indywidualnej, wspólnotowej i lokalnej. Ponadto uwypuklają dynamikę, aktywność, ilość i jakość interakcji, jak również określone formy kontaktów w zróżnicowanym kulturowo społeczeństwie.

Uwzględniając dokonane dywagacje, analizę problemu wielokulturowości osób osadzonych w zakładach karnych można oprzeć na ta-

2 Por. M. Golka, Oblicza wielokulturowości, [w:] U progu wielokulturowości. Nowe oblicza społeczeństwa polskiego, red. M. Kempny, A. Kapciak, S. Łodziński, Warszawa 1997, s. 54-55.

Z kolei zdaniem J. Nikitorowicza wielokulturowość w ujęciu dynamicznym jest wieloczynnikowa i wielozakresowa. Należy ją określać terytorialnie — w kontekście zasiedziałości, a także procesualnie — w kontekście ujawniających się odrębności, ożywiania ruchów etnicznych, narodowościowych, powstawania nowych, niepodległych państw. Ponadto - w kontekście migracji i dokonujących się procesów demokratyzacji (zapożyczenia, akulturacja, asymilacja, integracja globalizacja), które uruchomiły poczucie odrębności i kreowania własnego „Ja” oraz spowodowały kształtowanie tożsamości wielowymiarowej (podwojonej, rozproszonej, rozszczepionej, hybrydowej), łączącej cechy specyficzne dla różnych kultur. Por. J. Nikitorowicz, Edukacja międzykulturowa wobec dylematów ksztaltowania tożsamości w spoteczeństwach wielokulturowych, [w:] Pedagogika i edukacja wobec nowych wspólnot i różnic w jednoczącej się Europie, red. E. Malewska, B. Śliwerski, Kraków 2002, s. 268. 
kiej oto ogólniejszej, operacyjnej definicji pojęcia „wielokulturowość”. Oznacza ono współwystępowanie na tej samej przestrzeni, w bezpośrednim sąsiedztwie bez wyraźnego rozgraniczenia albo w sytuacji aspiracji do zajęcia tej samej przestrzeni dwóch lub więcej grup kulturowych o odmiennych cechach dystynktywnych, wpływających na określony typ interakcji indywidualnych i międzywspólnotowych, określając formy koegzystencji na styku kultury dominującej oraz mniejszościowych grup kulturowych, przy jednoczesnym zachowaniu tożsamości każdej z nich.

Jak pokazują wyniki licznych badań, cechami dystynktywnymi grup kulturowych funkcjonujących na stykach kultur, które przesądzają o kulturowej autoidentyfikacji, zarówno jednostkowej, jak i wspólnotowej, są przede wszystkim: narodowość ${ }^{3}$, etniczność ${ }^{4}$, język oraz religia. Ponieważ cechy te mogą mieć znaczenie dla środków i metod pracy penitencjarnej z takimi grupami, warto je w tym kontekście nieco dokładniej określić.

Narodowość osoby pozbawionej wolności będzie oznaczała przynależność do określonego narodu. Narodem zaś jest zbiorowość polityczna, którą cechuje więź formalna, czyli prawa i obowiązki określone ustawą zasadniczą (konstytucją). Łączy ona członków zbiorowości (obywateli) z państwem ${ }^{5}$, którego jurysdykcja odnosi się do ściśle określonego terytorium ${ }^{6}$. Cechuje ją wspólnota komplementarnych nawyków komuniko-

${ }^{3}$ E. Wnuk-Lipiński, Świat międzyepoki, Kraków 2004, s. 216.

${ }^{4}$ Etniczność oznacza praktyki kulturowe oraz zapatrywania danej społeczności ludzkiej, odróżniające ją od innych społeczności. Charakteryzuje ją zespół podstawowych cech wyróżniających daną zbiorowość pod względem historycznie ukształtowanej jej wewnętrznej spoistości społeczno-kulturowej (wspólnota pochodzenia, języka, wyznania, terytorium, obyczajowość), rozpoznawanych jako „swoich” i przez to samo wyodrębniających ją od innych wspólnot postrzeganych jako „obce”. Etniczność jest poczuciem wspólnoty dziedzictwa społeczno-kulturowego, która przejawia się w wielu sferach życia indywidualnego i zbiorowego. Wpływa w oczywisty sposób na postawy moralne i życie religijne członków zbiorowości etnicznych. Por. A. Giddens, Socjologia, Warszawa 2005, s. 270; J. Gajda, Etniczność i obywatelskość trudnym problemem edukacyjnym nie tylko „,Nowej Europy”, [w:] Etniczność i obywatelskość w Nowej Europie. Konteksty edukacji międzykulturowej, red. J. Nikitorowicz, D. Misiejuk, M. Sobecki, Białystok 2007, s. 30.

5 J. Gajda, op. cit., s. 30.

${ }^{6}$ E. Wnuk-Lipiński, op. cit., s. 216. 
wania się oraz uznawanie określonych wartości widocznych w określonych treściach kulturowych ${ }^{7}$.

Z kolei pojęcie etniczności określonej grupy osadzonych zdaniem A. Giddensa należy odnieść do kulturowych praktyk i zapatrywań danej społeczności ludzkiej, odróżniających ją od innych społeczności ${ }^{8}$. Charakteryzuje ją zespół podstawowych cech wyróżniających daną zbiorowość etniczną pod względem historycznie ukształtowanej jej wewnętrznej spoistości społeczno-kulturowej (wspólnoty pochodzenia, języka, wyznania, terytorium, obyczajowości), rozpoznawanych jako „swoich” i przez to samo wyodrębniających ją od innych wspólnot postrzeganych jako „obcych”9 . Stanowi zatem poczucie wspólnoty dziedzictwa społeczno-kulturowego, która przejawia się w wielu sferach życia indywidualnego i zbiorowego ${ }^{10}$. Musi zatem wpływać na postawy moralne i życie religijne osadzonych pochodzących ze zbiorowości etnicznych innych niż polska.

Jeszcze inną cechą autoidentyfikacji osoby osadzonej w zakładzie karnym, w związku z wykonaniem kary pozbawienia wolności albo też tymczasowego aresztowania, jest język. Umożliwia on (bądź nie) komunikację ze skazanym, ma zatem podstawowe znaczenie w pracy penitencjarnej. Pojęciem tym oznacza się wytwór interakcji społecznych będący wyuczonym i przekazywanym integralnym systemem znaków oraz ich znaczeń. Jako element kultury jest on podstawowym narzędziem (i zarazem nośnikiem) komunikacji, tworzenia i utrzymywania więzi społecznych, poznawania i interpretacji rzeczywistości, poznawania i interpretacji świadomości i samoświadomości oraz kumulacji dorobku kulturowego (w formie pisemnej) ${ }^{11}$. Stanowi zatem istotny czynnik identyfikacji oraz przesądza o wartości kultury rodzimej (jest jej rdzeniem i nośnikiem, źródłem twórczości i aktywności gospodarczej) ${ }^{12}$. W przypadku grupy

7 M. Sobecki, Etniczność a obywatelskość. Dwa wymiary identyfikacji narodowej, [w:] Etniczność i obywatelskość w Nowej Europie..., s. 72.

8 A. Giddens, op. cit., s. 270.

9 J. Gajda, op. cit., s. 30.

10 M. Gawęcki, Islam, etniczność i polityka w Azji Środkowej, [w:] Etniczność a religia, red. A. Posern-Zieliński, Poznań 2003, s. 191.

11 M. Ziółkowski, Język, [w:] Encyklopedia socjologii, red. W. Kwaśniewicz, Warszawa 1998, s. 373.

12 J.J. Smolicz, Współkultury Australii, Warszawa 1999, s. 148. 
kulturowej zabezpiecza jej trwanie, będąc elementem przekazywania z pokolenia na pokolenie dziedzictwa kulturowego, narzędziem komunikacji wewnątrzgrupowej oraz czynnikiem identyfikacji i zachowania tożsamości ${ }^{13}$.

Kolejną cechą wielokulturowości, która może być traktowana jako predykat sposobu prowadzenia pracy penitencjarnej, jej środków metod i treści, jest religia. Pojęciem tym oznacza się złożony system społeczny obejmujący zarówno elementy świadomości, jak i realne urządzenia społeczne czy atrybuty wiary. Jako elementy religii wskazuje się doktrynę, kult, organizację oraz przeżycia ludzkie. Religia tworzy i organizuje małe i wielkie grupy społeczne, wyznacza hierarchie, normy, wartości i obyczaje. Porządkuje rzeczywistość, czyniąc z niej zjawisko zrozumiałe i przewidywalne. Określa biologiczny i symboliczny byt człowieka w świecie. Wyznacza wzory sieci interakcji, buduje systemy społeczne, nadając człowiekowi role społeczne i normy, których powinien przestrzegać ${ }^{14}$.

Dla pracy penitencjarnej szczególne znaczenie ma to, że religia jest zbiorem darzonych poszanowaniem i czczonych symboli związanych z rytuałami, czyli obrzędami (na przykład nabożeństwa kościelne), w których uczestniczy społeczność wiernych ${ }^{15}$. Ma zatem wymiar instytucjonalny, będący wyrazem życia wspólnotowego, który tworzy tożsamość wspólnoty.

Religia wyznacza obszar przeżyć indywidualnych człowieka, kształtuje jego doświadczenia i ma związek ze sferą uczuć ${ }^{16}$. W takim stanie rzeczy jej uwzględnienie w pracy penitencjarnej może mieć bardzo istotne znaczenie, szczególnie dla osiągnięcia efektu poprawy moralnej skazanego, w dalszej perspektywie także i społecznej. Do najpowszechniejszych religii monoteistycznych współczesnego świata należy zaliczyć judaizm, chrześcijaństwo oraz islam, a do religii Dalekiego Wschodu hinduizm, buddyzm, konfucjanizm oraz taoizm ${ }^{17}$. Jak uczy obserwacja polskiej rzeczywistości społecznej, a także ukształtowanej pod jej wpły-

13 J. Nikitorowicz, Pogranicze, tożsamość, edukacja, Białystok 2001, s. 113.

14 T. Paleczny, Sekty. W poszukiwaniu utraconego raju, Kraków 1998, s. 10.

15 A. Giddens, op. cit., s. 554.

16 T. Paleczny, op. cit., s. 10.

17 Ibidem, s. 555-559. 
wem współczesnej przestrzeni penitencjarnej, dla polskiego więziennictwa znaczenie mogą jednak mieć tylko pierwsze trzy z nich, zwłaszcza zaś chrześcijaństwo.

Zaproponowane ujęcie wielokulturowości, a także specyfika cech dystynktywnych przesądzających o kulturowej odmienności, skłaniają do wskazania następujących obszarów kompensacyjnych w pracy penitencjarnej z osobami pochodzącymi z kultur odmiennych od polskiej. Chodzi więc w niej o usuwanie czy też nie dopuszczenie do:

1. marginalizacji osadzonego pochodzącego z innej kultury niż polska - jego postawa w procesie wykonania kary pozbawienia wolności może bowiem oznaczać wycofywanie się poza obszar kultury, wejście do podkultury marginesu społecznego; jest to najczęściej związane z nieudolną akulturacją;

2. separacji - oznacza ona odgrodzenie się bądź zdystansowanie jednostki lub grupy od wpływów nowego i obcego środowiska oraz organizację życia w obrębie własnej dotychczasowej grupy etnicznej; w warunkach więziennych może polegać na zdystansowaniu się od podejmowanych oddziaływań penitencjarnych, a także wyizolowaniu osadzonego w grupie wychowawczej.

Mając na uwadze wskazane niebezpieczeństwa, jako najważniejszy cel pracy penitencjarnej z osobami pochodzącymi z różnych kultur można wskazać ich integrację przy poszanowaniu ich międzykulturow ości. Integracja byłaby tu celem maksymalnym, w pewnym sensie także idealnym, tym samym trudnym do zrealizowania w warunkach zakładu karnego. Oznaczałaby bowiem włączenie osadzonego do procesu konstruowania nowej tożsamości kultury kraju osiedlenia. Wzbudzanie woli współdziałania w procesie kształtowania społecznie pożądanych postaw $^{18}$ musiałoby zatem opierać się o uznanie wielokulturowości. $\mathrm{W}$ programach pracy penitencjarnej przejawiałoby się to w realizowaniu programów czy też strategii rządowych, umożliwiających zachowanie kultury rodzimej (kultury pochodzenia). O ile mi wiadomo, jak dotychczas takich programów penitencjarnych w Polsce nie ma.

Wzgląd na międzykulturowość jest więc dyrektywą w pracy penitencjarnej. Oznacza dialogowe współistnienie osadzonego odmienne-

18 Art. 67 § 1 k.k.w. 
go kulturowo na styku z kulturą innych osadzonych, a także personelu więziennego. Taki dialog powinien opierać się na aksjologii wykreowanej $\mathrm{w}$ wyniku codziennych interakcji penitencjarnych na pograniczu kulturowym ${ }^{19}$.

Tak wyznaczony cel oddziaływań penitencjarnych może także zakładać asymilację osadzonego. Oznaczałaby ona rezygnację z kultury pochodzenia (rodzimej), odcięcie więzów z krajem pochodzenia przodków, a w konsekwencji pełne wejście w obszar kultury dominującej (polskiej). Należy jednak z całą mocą podkreślić, że oddziaływania w tym zakresie nie mogą być przymusowe, naruszałyby bowiem prawa człowieka ${ }^{20}$.

Ponieważ kwestie omawiane w tej części artykułu dotyczą ogólniejszych zagadnień związanych z wielokulturowością osób osadzonych w zakładach karnych, w tym również definicyjnych, należy jeszcze nieco uwagi poświęcić pojęciu „cudzoziemiec”. Pewna część osadzonych z tej grupy taki właśnie status prawny posiada. Pojęcie to akty prawa międzynarodowego określają w sposób pośredni przez odwołanie się do innego terminu — „uchodźca”. Tak czynią art. 1 Konwencji genewskiej dotyczącej statusu uchodźców z 28 lipca 1951 roku $^{21}$ oraz Protokół nowojorski $^{22}$. Na podstawie o zaproponowanej w nich wykładni można więc

19 Zob. A. Szerląg, Axiology of socialisation in families of nationally dualistic provenance, „Lithuanian University of Educational, Pedagogika” 116, 2014, nr 4, s. 64-74; A. Szerląg, S. Walasek, Kulturowy potencjat wychowania w rodzinie na styku kultur orientacje rodziców i dzieci, „Wychowanie w Rodzinie” 2014, nr 1, s. 23-41.

20 Por. na przykład Konwencja o ochronie praw człowieka i podstawowych wolności sporządzona w Rzymie dnia 4 listopada 1950 r. z późn. zmian. (Dz.U. z dnia 10 lipca 1993 r.). Por. art. 9: „1. Każdy ma prawo do wolności myśli, sumienia i wyznania; prawo to obejmuje wolność zmiany wyznania lub przekonań oraz wolność uzewnętrzniania indywidualnie lub wspólnie z innymi, publicznie lub prywatnie, swego wyznania lub przekonań przez uprawianie kultu, nauczanie, praktykowanie i czynności rytualne. 2. Wolność uzewnętrzniania wyznania lub przekonań może podlegać jedynie takim ograniczeniom, które są przewidziane przez ustawę i konieczne w społeczeństwie demokratycznym z uwagi na interesy bezpieczeństwa publicznego, ochronę porządku publicznego, zdrowia i moralności lub ochronę praw i wolności innych osób. Wolność myśli, sumienia i wyznania".

${ }^{21}$ Konwencja genewska z dnia 28 lipca 1951 r. - ratyfikowana przez Polskę, Dz.U. 1991 r. Nr 119, poz. 515, 517.

22 Protokół dotyczący statusu uchodźców, sporządzony w Nowym Jorku dnia 31 stycznia 1967 r., Dz.U. z 1991 r. Nr 119, poz. 517. 
przyjąć, że cudzozi em cem jest osoba, która przebywa poza swoim krajem pochodzenia i nie posiada obywatelstwa kraju pobytu ${ }^{23}$. Takie określenie jest zbieżne $\mathrm{z}$ definicjami zawartymi w ustawach krajowych państw europejskich ${ }^{24}$. Warto przy tym zwrócić uwagę na relację pomiędzy pojęciami „cudzoziemiec” i „uchodźca”. Uchodźstwo jest pewną szczególną sytuacją życiową człowieka, która wiąże się z uzasadnioną obawą przed prześladowaniem ze względu na rasę, religię, narodowość, przynależność do określonej grupy społecznej lub poglądy polityczne. W takim kontekście uchodźcą jest cudzoziemiec, który z powodu tej obawy nie może lub nie chce korzystać z ochrony własnego kraju pochodzenia. Z uwagi na to może ubiegać się o status uchodźcy, pozostając w granicach obcego państwa. Obejmują go jednak tak zwane klauzule wyłączające. Uchodźcą zatem nie może być osoba, która popełniła zbrodnię przeciwko pokojowi, zbrodnię wojenną, zbrodnię przeciw ludzkości bądź też poważne przestępstwo o charakterze niepolitycznym. Takie uściślenie nabiera znaczenia, gdy dana osoba (cudzoziemiec) ubiega się o status uchodźcy lub o zgodę na pobyt tolerowany. W konsekwencji stosowania tych klauzul może być aresztowana. Wśród osób tymczasowo aresztowanych w związku z podejrzeniem popełnienia lub uczestnictwa w przestępstwie znajdują się cudzoziemcy, co do których toczy się postępowanie o nadanie im statusu uchodźcy bądź tacy, którzy status ten już posiadają.

\section{Wielokulturowość w polskim prawie penitencjarnym}

Z ogólnych uwag o problemie wielokulturowości osób osadzonych w polskich zakładach karnych wynika, że problem ten w postępowaniu penitencjarnym można analizować w odniesieniu do dwóch grup osadzo-

23 Art. 2 i 3 ustawy o cudzoziemcach z 13 czerwca 2003 r. Dz.U. 2003 r. Nr 128, poz. 1175 z późn. zm.; art. 2 ustawy o udzielaniu cudzoziemcom ochrony na terytorium RP z 13 czerwca 2003 r., Dz.U. Nr 128, poz. 1176. z późn. zm.

24 J. Celej, Pojęcie cudzoziemca i obywatela UE. Prawo europejskie w praktyce, http://pewp.pl/index.php?option=com_content\&view=article\&id=111:pojcie-cudzoziemca-i-obywatelstwa-ue-\&catid=41:opinie-ekspertyzy-badania\&Itemid=60 (dostęp: 21.01.2015). 
nych: 1. pochodzących z różnych kultur, religii, posługujących się różnymi językami, prezentujących odmienne zwyczaje; 2 . cudzoziemców.

W tej części artykułu przeanalizuję zatem, jak problem postępowania $\mathrm{z}$ nimi jest obecnie unormowany w odpowiednich przepisach prawnych. Przyjmuję tu założenie, że jego regulacja dotyczy dwóch aspektów:

1. procedur formalnych, jakie funkcjonariusze podejmują wobec aresztowanych lub skazanych, o których była mowa pierwszej części niniejszego tekstu, oraz cudzoziemców;

2. zaleceń prawa międzynarodowego, dotyczących ogólnych reguł pracy z tą grupą osadzonych, a także stopnia ich uwzględnienia w prawie krajowym.

Już na wstępie takiej analizy można ocenić, że oba aspekty w polskim prawie penitencjarnym są uwzględnione w stopniu śladowym. Taka ocena wymaga uzasadnienia opartego na przeglądzie odpowiednich aktów polskiego prawa penitencjarnego.

Co do pierwszego z tych aspektów, należy wskazać, że prawne unormowania odpowiednich penitencjarnych procedur formalnych reguluje kodeks karny wykonawczy z 6 czerwca 1997 roku. Przegląd zawartych w nim przepisów upoważnia do wniosku, że nie dostrzeżono w nich problemu wielokulturowości osadzonych. Tak więc z uwagi na to, iż nie uwzględnia on zjawiska wielokulturowości, do osadzonych, o których mowa powyżej w pkt 1 i 2, stosuje się procedury ogólne. Analizując je pod kątem ewentualnej przydatności do postępowania $\mathrm{z}$ osobami pochodzącymi z różnych kultur oraz cudzoziemcami, można na wstępie wskazać art. 8 k.k.w. Wynika z niego, że w postępowaniu wykonawczym skazany może korzystać z pomocy obrońcy ustanowionego w tym postępowaniu ( $(1)$. Prawo do obrony wynika $\mathrm{z}$ odpowiednich postanowień Konstytucji RP. Zgodnie z jej art. 42 ust. 2, każdy (a więc także osoby, o których mowa w tym artykule), przeciwko komu prowadzone jest postępowanie karne, ma prawo do obrony we wszystkich stadiach postępowania (a więc także w postępowaniu wykonawczym). Może on w szczególności wybrać obrońcę lub na zasadach określonych w ustawie korzystać z obrońcy z urzędu". Prawo to jest zagwarantowane również przez normy traktatowe w zakresie ochrony praw człowieka (art. 14 ust. 3 lit. b i d Międzynarodowego paktu praw obywatelskich i politycz- 
nych z 19 grudnia 1966 roku $^{25}$ oraz art. 6 ust. 3 lit. c Konwencji o ochronie praw człowieka i podstawowych wolności z 4 listopada 1950 roku $^{26}$. Jak zatem widać, stopień ogólności albo blankietowości tego rodzaju zapisów, jeśli odnosić je do osób prezentujących różne kultury oraz cudzoziemców osadzonych w polskich zakładach karnych, jest bardzo wysoki. Ich prawo do obrońcy zostało również pominięte w art. $8 \S 2$ k.k.w. $\mathrm{Z}$ treści tego przepisu wynika, że w postępowaniu przed sądem skazany musi mieć obrońcę, jeżeli:

1. jest głuchy, niemy lub niewidomy;

2. zachodzi uzasadniona wątpliwość co do jego poczytalności;

3. nie ukończył 18 lat;

4. sąd uzna to za niezbędne ze względu na okoliczności utrudniające obronę.

Zaskakujące jest to, że poprzednio obowiązujący pkt 4, który przewidywał obowiązek ustanowienia obrońcy dla osoby niewładającej językiem polskim, został uchylony ustawą z dnia 16 września 2011 roku $^{27}$. Jak zatem widać, zakres pomocy i możliwości udzielenia pomocy prawnej cudzoziemcom uległ niekorzystnemu dla nich zawężeniu. Osadzeni pochodzący z odmiennych kultur oraz obszarów językowych otrzymują ją z odpowiednich placówek konsularnych. W postępowaniu przed sądami polskimi nie są obecnie reprezentowani przez adwokatów z urzędu. Mogą jedynie korzystać z pomocy tłumaczy przysięgłych. W takim stanie rzeczy powstaje pytanie o niezbędność obrony. S. Lelental w swoim komentarzu do kodeksu karnego wykonawczego zwraca uwagę, że upośledzenia w zakresie porozumiewania się, jako podstawa obowiązkowej obrony formalnej, powinny być oceniane w trybie 79 § 2 k.p.k. ${ }^{28}$ Wynika $\mathrm{z}$ tego, że decyzja o tym, czy skazany musi mieć obrońcę ze względu na to, że nie włada językiem polskim, należy do sądu penitencjarnego. Jest ona fakultatywna, opiera się bowiem na ocenie, czy ze względu na inną okoliczność, jaką jest nieznajomość języka polskiego, utrudniającą obronę, jest to niezbędne czy też nie ${ }^{29}$. Wypada zauważyć, że ustawowe

25 Dz.U z 1977 r. Nr 38, poz. 167.

26 Dz.U. z 199 r. Nr 61, poz. 284 ze zm.

27 Dz.U. Nr 240, poz. 1431.

28 S. Lelental, Kodeks karny wykonawczy, Warszawa 2014, s. 78.

29 T. Grzegorczyk, Kodeks postępowania karnego, Warszawa, s. 278. 
ujęcie braku znajomości języka w grupie innych okoliczności świadczy o obecnym obniżeniu rangi tego problemu. Dość trudno znaleźć argumentację za taką nowelizacją dawnej treści analizowanego przepisu.

Tyle ogólne postanowienia kodeksowe. Poszukując prawnych unormowań wielokulturowości ukierunkowanych specjalnie na osadzonych pochodzących z różnych kultur oraz cudzoziemców, łatwo dojść do wniosku, że zasadniczo ich brakuje. Pojawiają się co prawda pewne przepisy, jednak regulują one kwestie drugorzędne, niejako techniczne. Dotyczą one tylko cudzoziemców. Można je znaleźć w rozporządzeniu Ministra Sprawiedliwości z dnia 2 października 2012 r. w sprawie czynności administracyjnych związanych z wykonywaniem tymczasowego aresztowania oraz kar i środków przymusu skutkujących pozbawieniem wolności oraz dokumentowania tych czynności (Dz.U. z 23 października 2012 r. poz. 1153). Rozporządzenie to określa, kto jest cudzoziemcem. Paragraf 1 pkt 2 stanowi, że użyte w nim określenie ,cudzoziemiec” oznacza osobę, o której mowa w art. 2 ustawy z dnia 13 czerwca 2003 r. o cudzoziemcach ${ }^{30}$. Zgodnie z treścią art. 2 tej ustawy „cudzoziemcem jest każdy, kto nie posiada obywatelstwa polskiego". Wynika z tego jasno, że może nim być osoba pochodząca z tego samego kręgu kulturowego, na przykład Czech lub Słowak.

Z punktu widzenia prawnej reglamentacji problemu wielokulturowości osób osadzonych w polskich jednostkach penitencjarnych wskazane rozporządzenie normuje więc kwestie trzeciorzędne, przy czym odnosi je wyłącznie do cudzoziemców. Tak należy bowiem ocenić problem dokumentów osobowych. Zgodnie z $\S 31.1$ pkt 2 tego rozporządzenia dokumentami służącymi do sprawdzenia tożsamości osoby przyjmowanej do takiej jednostki są w wypadku cudzoziemca dokument podróży, karta stałego pobytu lub karta czasowego pobytu, wydane przed dniem 1 lipca 2001 r., karta pobytu wydana po dniu 1 lipca 2001 roku, polski dokument tożsamości cudzoziemca, polski dokument podróży dla cudzoziemca, tymczasowy polski dokument podróży dla cudzoziemca, wreszcie tymczasowe zaświadczenie tożsamości cudzoziemca.

Inną czynnością techniczną w postępowaniu penitencjarnym z cudzoziemcami jest ich ewidencja. Kwestię tę normuje wskazane już roz-

30 Dz.U. z 2011 r. Nr 264, poz. 1573; oraz z 2012 r. poz. 589 i 769. 
porządzenie Ministra Sprawiedliwości z dnia 2 października 2012 r. w sprawie czynności administracyjnych związanych $\mathrm{z}$ wykonywaniem tymczasowego aresztowania oraz kar i środków przymusu skutkujących pozbawieniem wolności oraz dokumentowania tych czynności. Koncentruje się ono na odmiennościach proceduralnych w tym zakresie. Ich znaczenie dla problemu wielokulturowości w środkach i metodach pracy penitencjarnej jest zatem — znów - marginalne. Chodzi bowiem o dokumenty tożsamości oraz ewidencję cudzoziemca będącego obywatelem więcej niż jednego państwa. Tak więc, zgodnie z $\$ 31.1$ pkt 2, dokumentami służącymi do sprawdzenia tożsamości osoby przyjmowanej są w wypadku cudzoziemca dokumenty wskazane wcześniej. Z kolei cudzoziemca będącego obywatelem dwóch lub więcej państw ewidencjonuje się jako obywatela tego państwa, którego dokument podróży stanowił podstawę wjazdu na terytorium Rzeczypospolitej (§ 65).

Resumując, należy podkreślić, że analiza dotychczasowych prawnopenitencjarnych unormowań problemu wielokulturowości osób osadzonych w polskich zakładach karnych pokazuje, że ustawodawca dostrzega potrzebę uregulowania jedynie kwestii organizacyjnych. Znacznie ważniejszym od nich obszarem jest praca penitencjarna, ściślej zaś jej treść, stosowane środki oraz metody. Powinny one uwzględniać jej specyfikę w odniesieniu do osób reprezentujących odmienne kultury, będące obywatelami polskimi, jak również cudzoziemców. Tych ostatnich można podzielić na tożsamych kulturowo z osadzonymi z kręgu kultury polskiej bądź od nich odmiennych. Warto zatem prześledzić pokrótce, czy tak rzeczywiście jest.

Analizując przepisy kodeksu karnego wykonawczego pod kątem uwzględnienia przez nie problemu wielokulturowości w pracy penitencjarnej, można łatwo zauważyć, że w zasadzie go nie dostrzegają. $Z$ tego powodu odpowiedź na pytanie, jak pracować z osobami reprezentującymi kultury inne niż polska, jest dość trudna. Należałoby jej poszukiwać $\mathrm{w}$ interpretacji per analogiam ustawowych ogólnych reguł pracy penitencjarnej. Regulacji szczegółowych w tym zakresie bowiem jak dotychczas brakuje.

Wobec takiej luki należy przyjąć, że do osadzonych pochodzących z różnych kultur, religii, posługujących się różnymi językami, prezentujących odmienne zwyczaje, jak również cudzoziemców, stosuje się te 
same przepisy prawa karnego, te same zasady procesowe oraz zasady odbywania kary co do pozostałych skazanych. Wynikałoby z tego jednak, że problem wielokulturowości w polskich zakładach karnych wyraźniej dostrzegany nie jest. Podkreślić należy, że z wielu powodów, włącznie z kulturą, językiem, zwyczajami, religią i społecznym wyobcowaniem, sytuacja osadzonego odmiennego kulturowo jest o wiele trudniejsza niż innych skazanych osób. Stopień dolegliwości i bólu spowodowanego uwięzieniem jest więc dla niego większy niż dla rodzimych obywateli ${ }^{31}$.

Mając to na uwadze, należy więc przeanalizować cztery podstawowe akty prawa penitencjarnego, określające zasady wykonania kary pozbawienia wolności. Pierwszym z nich, w randze ustawy, jest kodeks karny wykonawczy z 6 czerwca 1997 r. (Dz.U. z 1997 r. Nr 90, poz. 557). Trzy kolejne to tak zwane akty okołokodeksowe. Chodzi o:

1. rozporządzenie Ministra Sprawiedliwości z dnia 25 sierpnia 2003 r. w sprawie regulaminu organizacyjno-porządkowego wykonywania kary pozbawienia wolności (Dz.U. 2003. Nr 152, poz. 1493);

2. rozporządzenie Ministra Sprawiedliwości z dnia 12 sierpnia 1998 r. w sprawie regulaminu wykonywania kary pozbawienia wolności (Dz.U. z dnia 26 sierpnia 1998 r.);

3. rozporządzenie Ministra Sprawiedliwości z dnia 14 sierpnia 2003 r. w sprawie sposobów prowadzenia oddziaływań penitencjarnych w zakładach karnych i aresztach śledczych (Dz.U. z dnia 29 sierpnia 2003 r.; tekst jedn. Dz.U. z 12 września 2013 r. poz. 1067).

Oceniając zawarte $\mathrm{w}$ nich regulacje $\mathrm{w}$ zakresie pracy penitencjarnej z osadzonymi pochodzącymi z różnych kultur, religii, posługujących się różnymi językami, prezentujących odmienne zwyczaje, a także cudzoziemcami, można ogólnie stwierdzić, że w zasadzie brakuje odniesień do problemu multikulturowości oraz cudzoziemców (na przykład przy klasyfikacji, rozmieszczeniu w celach, pracy, nauczaniu, zajęciach k.o). Można by doszukać się ich jedynie w zakresie wolności religijnej osadzonych oraz prawa do informacji (i to tylko per analogiam - por. art. 101 k.k.w., art. 102 pkt 3 k.k.w.), a także ich prawa do korespondencji (regulacja wprost — por. art. $105 \S 2$ k.k.w.).

31 M. Płachta, Transfer of proceedings and transfer of prisoners, 3 CJIL, 1988. 
Charakteryzując przedstawione fakty bardziej szczegółowo, wypada wskazać, że problemu odmienności kulturowych nie uregulowano w tym kodeksie przy określeniu takich zagadnień, jak:

— indywidualizacja wykonania kary oraz klasyfikacja skazanych (por. art. 79-100 k.k.w.),

— prawa i obowiązki osadzonych (por. art. 101-120 k.k.w.),

— zatrudnienie (por. art. 121-129 k.k.w.),

- nauczanie osadzonych (por. art. 130-134 k.k.w.),

— zajęcia kulturalno-oświatowe i sportowe (por. art. 135-136 a k.k.w.),

— nagrody i ulgi (por. art. 137-141 a k.k.w.),

— kary dyscyplinarne (por. art. 142-149 k.k.w.).

Wskazanych zagadnień nie uregulowano także $\mathrm{w}$ tak zwanych okołokodeksowych aktach prawa wykonawczego, a więc w przepisach szczegółowych.

Tytułem przykładu zaniechań w tym zakresie można przywołać treść art. $82 \S 1$ k.k.w. Stanowi on, że w celu stwarzania warunków sprzyjających indywidualnemu postępowaniu ze skazanymi, zapobieganiu szkodliwym wpływom skazanych zdemoralizowanych oraz zapewnieniu skazanym bezpieczeństwa osobistego, wyboru właściwego systemu wykonywania kary, rodzaju i typu zakładu karnego oraz rozmieszczenia skazanych wewnątrz zakładu karnego, dokonuje się ich klasyfikacji. Jak zatem widać, eksponując indywidualizację oddziaływań, przepis ten nie wspomina o odniesieniu ich do wielokulturowości. Na odmienność kulturową nie wskazuje się też w katalogu kryteriów klasyfikacji skazanych. W związku z tym trzeba przypomnieć, że zgodnie z treścią § 2 owego przepisu takimi kryteriami są: 1 . płeć, 2. wiek, 3. uprzednie odbywanie kary pozbawienia wolności, 4. umyślność lub nieumyślność czynu, 5. czas pozostały do odbycia kary pozbawienia wolności, 6 . stan zdrowia fizycznego i psychicznego, w tym stopień uzależnienia od alkoholu, środków odurzających lub psychotropowych, 7. stopień demoralizacji i zagrożenia społecznego, 8. rodzaj popełnionego przestępstwa.

Kryterium wielokulturowości nie uwzględnia się również przy rozmieszczeniu osadzonych w celach. Oto bowiem $\S 11$ rozporządzenia Ministra Sprawiedliwości z dnia 25 sierpnia 2003 r. w sprawie regulaminu organizacyjno-porząakowego wykonywania kary pozbawienia wolności (Dz.U. 2003 Nr 152, poz. 1493) stanowi: „skazanych rozmieszcza 
się w celach, uwzględniając w szczególności płeć, wiek oraz uprzednie odbywanie zasadniczej kary pozbawienia wolności albo kary aresztu wojskowego".

Jak zatem widać, na przykład osadzony muzułmanin nie może liczyć na takie urządzenie warunków wykonania kary pozbawienia wolności, które umożliwiałyby ścisłe przestrzeganie zasad wiary w zakresie wyżywienia, wykonywanej pracy, przerw na modlitwę czy w ogóle wykonywanie praktyk religijnych ${ }^{32}$. W związku z tym warto przypomnieć treść Europejskich Reguł Więziennych w zakresie gwarancji wolności myśli, sumienia i wyznania. Reguła 29.1 nakazuje szanować wolność myśli, sumienia i wyznania więźniów. Kolejna reguła - 29.2 — stanowi, że rygor więzienny o tyle, o ile to możliwe, pozwala więźniom na praktykowanie ich religii i wyznań, uczestniczenie w nabożeństwach lub spotkaniach prowadzonych przez zaaprobowanych przedstawicieli tych religii lub wyznań, przyjmowanie wizyt duszpasterskich składanych przez przedstawicieli takich religii i wyznań oraz posiadanie książek lub literatury z zakresu ich lub wyznań. Wreszcie, zgodnie z regułą 29.3, więźniowie nie mogą być zmuszani do praktykowania religii lub wyznań, uczestniczenia w nabożeństwach lub przyjmowania wizyt duszpasterskich składanych przez przedstawicieli jakiejkolwiek religii i wyznania.

Kiedy przytaczam wskazane reguły, przypominam sobie moje wizyty w polskich zakładach karnych, na przykład we Wronkach. Podczas nich rutynowo pokazywano mi kaplice więzienne, na ogół zresztą na co dzień zamknięte. Kiedy jednak pytałem, czy są one przystosowane do potrzeb więźniów wyznających religię inną niż katolicka, następowało kłopotliwe, wymowne milczenie. Cóż, póki co w większości regionów Polski, problem jest marginalny ${ }^{33}$. Niemniej jednak jest, a w przyszłości będzie narastał wraz z falą emigrantów, na przykład z krajów Dalekiego

32 Por. art. $107 \S 1$ k.k.w. Wprowadza on zasadę osobnego rozmieszczenia jedynie skazanych za przestępstwo popełnione $\mathrm{z}$ określonej motywacji, tj. politycznej, religijnej lub przekonań ideowych. Odbywają oni karę w oddzieleniu od skazanych za inne przestępstwa, mają prawo do korzystania z własnej odzieży, bielizny i obuwia oraz nie podlegają obowiązkowi pracy. Nie dotyczy to więc skazanych odmiennych kulturowo, wyznających różne religie.

33 Wschodnie województwa Polski są zamieszkiwane także przez ludność wyznania prawosławnego. Zgodnie z Rocznikiem Statycznym Rzeczypospolitej Polskiej (Warszawa 2016) w końcu roku 2016 osób takiego wyznania było 506123. 
Wschodu (Wietnam, Kambodża, Laos, Birma itp.) a także z krajów arabskich, zwłaszcza z ogarniętej wojną domową Syrii.

Warto zatem przywołać w tym miejscu treść art. 102 k.k.w. Stanowi on póki co, że skazany ma prawo do:

1. odpowiedniego ze względu na zachowanie zdrowia wyżywienia, odzieży, warunków bytowych, pomieszczeń oraz świadczeń zdrowotnych i odpowiednich warunków higieny;

2. utrzymywania więzi z rodziną i innymi osobami bliskimi;

3. korzystania $\mathrm{z}$ wolności religijnej;

4. korzystania z urządzeń i zajęć kulturalno-oświatowych i sportowych, radia, telewizji, książek i prasy.

Prawo do korzystania z wolności religijnej zostało rozwinięte w art. $106 \S 1$ k.k.w. ${ }^{34}$ Chociaż wymienia on ogólnie różne formy korzystania z tej wolności, to jednak nie wskazuje, jak mają to zrobić skazani reprezentujący religie odmienne od katolickiej. W konsekwencji ogólny zapis ustawowy wprawdzie istnieje, jak jednak wskazałem przed chwilą, w polskich zakładach karnych ciaggle jeszcze brakuje odpowiedniej infrastruktury, która umożliwiałaby jego realizację w ich konkretnych warunkach.

Inna kwestia, nad którą nie można przejść obojetnie, to zagadnienie wyżywienia. Jak wynika z treści art. 102 pkt 1 k.k.w., zróżnicowanie wyżywienia przewidziane jest tylko ze względów zdrowotnych, przy pominięciu religijnych. To samo można odnieść do prawa osadzonego do korzystania z urządzeń i zajęć kulturalno-oświatowych i sportowych, radia, telewizji, książek i prasy. Pytaniem otwartym pozostaje bowiem, jakich, w jakim języku.

Pytaniem otwartym pozostaje także kwestia, jak zabezpieczyć osadzonemu reprezentującemu kulturę odmienną od polskiej, na dodatek

${ }^{34}$ Zgodnie z jego treścią skazany ma prawo do wykonywania praktyk religijnych i korzystania z posług religijnych oraz bezpośredniego uczestniczenia w nabożeństwach odprawianych w zakładzie karnym w dni świąteczne i słuchania nabożeństw transmitowanych przez środki masowego przekazu, a także do posiadania niezbędnych w tym celu książek, pism i przedmiotów. Z kolei § 2 stanowi, że skazany ma prawo do uczestniczenia w prowadzonym w zakładzie karnym nauczaniu religii, brania udziału w działalności charytatywnej i społecznej kościoła lub innego związku wyznaniowego, a także do spotkań indywidualnych z duchownym kościoła lub innego związku wyznaniowego, do którego należy; duchowni ci mogą odwiedzać skazanych w pomieszczeniach, w których przebywają. 
niewładającemu językiem polskim, prawo do utrzymywania więzi z rodziną i najbliższymi, do których w pracy penitencjarnej przykłada się tak dużą wagę ${ }^{35}$.

Kończąc ten krótki przegląd polskich unormowań w zakresie problemu wielokulturowości osób osadzonych w zakładach karnych, a raczej widocznych w nich zasadniczych wręcz luk i braków, zwrócę uwagę jeszcze na problem informacji. Informowanie skazanych o ich prawach i obowiązkach, jak również założeniach, celach, środkach i metodach podejmowanych wobec nich oddziaływań penitencjarnych, jest jednym z podstawowych obowiązków organów wykonawczych, zwłaszcza zaś służby więziennej.

$\mathrm{Na}$ prawo osadzonego w jednostce penitencjarnej do informacji wskazuje wiele aktów prawa międzynarodowego, w tym między innymi Europejskie Reguły Więzienne. Ich postanowienia zostały recypowane w prawie polskim. Warto zatem przypomnieć, iż w regule 30.1 ERW postanowiono, że w momencie przyjęcia i zawsze później, gdy istnieje taka potrzeba, wszyscy więźniowie informowani są pisemnie i ustnie o przepisach regulujących dyscyplinę więzienną oraz o ich prawach i obowiązkach w zakładzie karnym. Z kolei reguła 30.2 stanowi, że więźniowie mają prawo posiadania pisemnej wersji przekazanych im informacji. Wreszcie, zgodnie z treścią reguły 30.3, więźniowie informowani są o jakimkolwiek postępowaniu mającym z nimi związek, a jeśli są skazani, o wymiarze kary do odbycia oraz możliwościach przedterminowego zwolnienia. Powstaje zatem pytanie, jak ustawodawca polski zagwarantował realizację prawa do informacji osadzonym odmiennym kulturowo. Już pobieżna analiza polskiego prawa penitencjarnego pod tym kątem pokazuje, że poprzestał on na deklaracjach ogólnych. Dotyczą one wszystkich skazanych, tak więc dla osadzonych reprezentujących odmienne kultury nie wynika z nich zbyt wiele. Gdyby osadzony tego rodzaju znalazł się w zakładzie karnym, stosowano by zatem ogólne postanowienia kodek-

35 Por. art. 105 § 1 k.k.w.: ,skazanemu należy umożliwiać utrzymywanie więzi przede wszystkim z rodziną i innymi osobami bliskimi przez widzenia, korespondencję, rozmowy telefoniczne, paczki i przekazy pieniężne, a w uzasadnionych wypadkach, za zgodą dyrektora zakładu karnego, również przez inne środki łączności, oraz ułatwiać utrzymywanie kontaktów z podmiotami, o których mowa w art. 38 podmioty współdziałające w wykonywaniu orzeczeń, $\S 1$ ”. 
su karnego wykonawczego. Zgodnie z nową redakcją art. 101 kodeksu karnego wykonawczego, która weszła w życie z dniem 1 lipca 2015 roku (Dz.U. z 2013 roku poz. 1247), należałoby „bezzwłocznie po osadzeniu go w zakładzie karnym poinformować o przysługujących mu prawach i ciążących na nim obowiązkach oraz o konsekwencjach wynikających z art. 139 § 1 kodeksu postępowania karnego, a zwłaszcza umożliwić mu zapoznanie się z przepisami niniejszego kodeksu i regulaminu organizacyjno-porządkowego wykonywania kary pozbawienia wolności”.

W stosunku do skazanych obowiązek zapoznania ich z podstawowymi aktami prawnymi dotyczącymi wykonywania kary pozbawienia wolności nakłada również art. 79b $\S 1$ k.k.w. ${ }^{36}$, w odniesieniu zaś do tymczasowo aresztowanych tożsama regulacja znajduje się w art. 210 k.k.w. ${ }^{37}$ Także w rozporządzeniach wykonawczych do kodeksu karnego wykonawczego, regulujących wykonywanie kary pozbawienia wolności oraz tymczasowego aresztowania, ustanawia się obowiązek przeprowadzenia ze skazanym lub tymczasowo aresztowanym rozmowy informacyjnej przez wychowawcę lub wyznaczonego przez niego funkcjonariusza. Jej celem ma być zapoznanie skazanego z prawami i obowiązkami oraz ustalonym w jednostce porządkiem wewnętrznym ${ }^{38}$.

36 „Skazanego przyjętego do aresztu śledczego umieszcza się w celi przejściowej, na okres niezbędny, nie dłużej jednak niż na 14 dni, dla poddania go wstępnym badaniom lekarskim, zabiegom sanitarnym, wstępnym badaniom osobopoznawczym oraz zapoznania z podstawowymi aktami prawnymi dotyczącymi wykonywania kary pozbawienia wolności i porządkiem wewnętrznym aresztu śledczego".

37 Art. 210 k.k.w.: „Przyjmując tymczasowo aresztowanego do aresztu śledczego należy go bezzwłocznie poinformować o przysługujących mu prawach i ciążących na nim obowiązkach oraz o konsekwencjach wynikających z art. $139 \S 1$ kodeksu postępowania karnego, a zwłaszcza umożliwić mu zapoznanie się z przepisami niniejszego kodeksu i regulaminu organizacyjno-porządkowego wykonywania tymczasowego aresztowania, oraz poddać odpowiednim badaniom lekarskim i zabiegom sanitarnym".

38 Por. na przykład § 2.1 rozporządzenia Ministra Sprawiedliwości z dnia 12 sierpnia 1998 r. w sprawie regulaminu wykonywania kary pozbawienia wolności (Dz.U. z dnia 26 sierpnia 1998 r.): „skazanego przyjętego do zakładu karnego umieszcza się w celi przejściowej, na okres niezbędny, nie dłużej jednak niż na 14 dni, dla poddania go wstępnym badaniom lekarskim, zabiegom sanitarnym i wstępnym badaniom osobopoznawczym oraz zapoznania z podstawowymi aktami prawnymi dotyczącymi wykonywania kary pozbawienia wolności i porządkiem wewnętrznym zakładu karnego. W celi przejściowej powinien znajdować się tekst kodeksu karnego wykonawczego, zwanego 
Powstaje jednak zasadnicze pytanie, w jakim języku to zrobić, jeśli osadzony nie włada językiem polskim. Problemu tego nie rozwiązała niestety decyzja Dyrektora Generalnego Służby Więziennej z dnia 31 marca 2014 r. (nr pisma BP-073-88/14/262). Wydał on w niej polecenie, aby wszystkie cele przejściowe $\mathrm{w}$ jednostkach penitencjarnych były wyposażone $\mathrm{w}$ informator dla skazanych. Informator ten stanowi kompendium podstawowej wiedzy dla osadzonych o przysługujących im prawach, uprawnieniach i obowiązkach, jest napisany w przystępnym stylu. Problemem jednak pozostaje to, że został opracowany tylko w polskiej wersji językowej. Jego przydatność dla osadzonych nieposługujących się językiem polskim, a także cudzoziemców, jest więc mocno ograniczona.

Realizacja prawa do informacji w takich wypadkach zatem będzie w praktyce zależeć od tego, czy dany zakład karny wykaże dobrą wolę, jak również czy znajdzie środki na przetłumaczenie jej na język zrozumiały dla skazanego (na przykład arabski, wietnamski, czeczeński). Podobny problem dotyczy zresztą thumaczenia samych aktów prawnych, normujących sposób wykonywania kary pozbawienia wolności oraz zasady pracy penitencjarnej. W tej sytuacji trudności komunikacyjne łagodzi nieco fakt, że zgodnie z art. $105 \S 2$ k.k.w. skazany cudzoziemiec może prowadzić korespondencję $\mathrm{z}$ właściwym urzędem konsularnym, a $\mathrm{w}$ razie braku takiego urzędu $-\mathrm{z}$ właściwym przedstawicielstwem dyplomatycznym oraz korzystać z widzeń z urzędnikiem konsularnym lub wykonującym funkcje konsularne pracownikiem przedstawicielstwa dyplomatycznego.

W podsumowaniu wszystkiego, co powiedziano w niniejszym tekście na temat wielokulturowości polskich systemie penitencjarnym, zwłaszcza zaś o zakresie jego uwzględnienia w reglamentacji prawnej, warto na koniec sformułować kilka wniosków ogólniejszych. Część $\mathrm{z}$ nich ma charakter postulatywny.

Wiedza o zjawisku wielokulturowości oraz związanej z nim potrzebie uwzględnienia go podczas odbywania kary pozbawienia wolności przez osoby kulturowo zróżnicowane jest — jak dotychczas — bardzo

dalej »kodeksem«, i regulaminu wykonywania kary pozbawienia wolności, zwanego dalej »regulaminem «". 
mała i powierzchowna. Pożądane zatem byłoby dokładniejsze zbadanie wielkości i charakteru tego zjawiska.

Ustalenia i zbadania wymagają zwłaszcza wszelkie przejawy kulturowego zróżnicowania osób odbywających karę pozbawienia wolności, w tym specyficzne ich postawy i zachowania, jak również warunki odbywania przez nie kary pozbawienia wolności. Gruntowa, rzetelna i wiarygodna diagnoza w tym zakresie jest nieodzowna. Wobec wskazywanych $\mathrm{w}$ artykule dotkliwych luk prawnych $\mathrm{w}$ zakresie uregulowania sposobu wykonywania tej kary, powstaje ważne i trudne pytanie o poszanowania praw, wartości i zwyczajów związanych z określonymi kulturami reprezentowanymi przez więźniów. Jednocześnie rodzi się pytanie o ich koherencję do wartości, postaw, zachowań oraz zasad współżycia społecznego przyjętych w Polsce - tu bowiem kara pozbawienia wolności jest wykonywana.

Warto zatem już dziś, przewidując, że problem wielokulturowości w zakładach karnych będzie narastał, podjąć dyskusję nad tym, czy i w jakim stopniu powinna być ona uwzględniona $\mathrm{w}$ regulacjach prawnych i porządkowych dotyczących odbywania tej kary oraz jak należałoby urządzić warunki odbywania kary pozbawienia wolności przez osoby kulturowo zróżnicowane, aby możliwe stało się rozwiązanie różnych $\mathrm{i}$ trudnych w tym zakresie kwestii wskazywanych w niniejszym artykule.

\section{Multiculturality in penal institutions. Remarks on the problem and legal norms}

Summary

The article is devoted to the multiculturality of the prison population. It has recently become one of the most important political, social and economic problems facing contemporary societies as well as an important and growing penal problem.

The article is divided into two parts. In part one the author discusses the terminology associated with multiculturality. He formulates his own, operational definition of the concept with regard to the contemporary penal space. In addition, he points to the distinctive features of inmates representing various cultures (nationality, ethnicity, language, religion), and discusses their significance in working with prisoners. In part two the author analyses how the question of multiculturality is tackled in the Polish prison law with regard to two groups of convicts: those from different cultural and religious back- 
grounds, speaking different languages and having different customs, as well as foreigners. He points to two areas of legal regulations, i.e. formal procedures applied by officers with regard to individuals under arrest or already sentenced as well as recommendations of international law concerning the general rules of working with this group of inmates, and the level to which they have been taken into account in Polish law. He concludes that the two aspects are barely noticed in Polish prison law. The author explains his opinion in detail, drawing on a review of relevant provisions of Polish prison law. The article ends with a call to investigate the scale and nature of the phenomenon in Polish penal institutions, as it will become more urgent in the future, which prompts questions about respect for the laws, values and customs associated with the cultures represented by prisoners, and, on the other hand, about their compatibility with the values, attitudes, behaviours and principles of social conduct accepted in Poland. The author calls for a discussion about how to organise custodial sentences for individuals from varied cultural backgrounds and how to expand the Polish prison regulations in this respect.

Keywords: multiculturality, penal institutions, prison law, convicts, work with prisoners. 